\title{
Geophysical Investigation and Management Plan of a Shallow Landslide along the NH-44 in Atharamura Hill, Tripura, India
}

\author{
Kapil Ghosh ${ }^{1}$, Shreya Bandyopadhyay ${ }^{1}$, Sunil Kumar De ${ }^{2 *}$ \\ ${ }^{1}$ Department of Geography and Disaster Management, Tripura University, 799022, India \\ ${ }^{2}$ Department of Geography, North Eastern Hill University, Shillong, 793022, India
}

\begin{abstract}
In any effective landslide hazard mitigation plan, in-depth knowledge about the causes of instability is required. Consequently, it is essential to study geological, geotechnical, meteorological and anthropogenic factors that influence the landslide. For the present study a geophysical investigation has been carried out on a large landslide, on the slopes of Tertiary siltstones, mudstones, shales and sandstones at Atharamura Hill, Tripura. Different techniques have been used, including measurement of micro-slope using Total Station, clinometers and the LISCAD software for terrain modeling and determining the total volume of the material displaced and total area affected by landslides and analysis of soil properties to understand the present condition of the scarps. Results obtained through field investigation and laboratory testing revealed that the underlying cause of the slide could be (a) the adverse geological formation with unconsolidated sandy materials and occasional intersection of silt or clay layers, (b) the hydrological condition with continuous seepage through fractures, and (c) cutting of hill slopes for reconstructing and widening of the road (NH44). This latter anthropogenic influence has been triggered by an intense precipitation event during the monsoon season.
\end{abstract}

Keywords: landslide, instability, hazard, geophysical investigation, human interference

\section{Introduction}

In India, about $10 \%$ of total population was affected by natural disaster in 2008; among this $0.5 \%$ of the population were affected by landslides only. According to the Geological Survey of India (GSI 2009), 0.49 million $\mathrm{km}^{2}$ or $15 \%$ of land area of this country is vulnerable to landslide hazard. Of the areas vulnerable to landslide hazard, 0.098 million $\mathrm{km}^{2}$ are located in the North-East region.

Landslides are common hazardous phenomena in hilly area of Tripura especially in North and Dhalai districts. Almost every monsoon period, when heavy downpours occur, this phenomenon takes place. The hilly terrain of Tripura is prone to landslides due to its geological instability, neo-tectonic activity (Sen et al 2015) and extreme rainfall infiltration during monsoon season (Fookes and Wilson 1966, Varnes 1978).

Moreover, rapid developmental activities, such as, construction of roads and railways through highly rugged hilly terrains, have intensified these hazardous phenomena in recent decades. The landslide incidences have reportedly increased ever since the road and other infrastructural developments have accelerated in hill areas (Ghosh et al 2012). Such infrastructural developments have significant impacts on life and property in many parts of Himalaya, especially in those areas with high population densities and land use. During intensive field survey, it is found that most of the landslides occurred along the national highway (NH-44). Blocked and damaged

* Corresponding Author: Sunil Kumar De, Email: desunil@gmail.com, Tel: +91 9862009202

DOI: 10.15273/ijge.2016.03.013 
roads as a result of landslide activity are common occurrences along the national highway corridors in Atharamura and Longtarai hilly areas following moderate to heavy rainfall (where moderate rainfall is defined as $2.5-7.6 \mathrm{~mm}$ per hour and heavy rainfall is $>7.6 \mathrm{~mm}$ per hour).

Landslides are considered important and complex hazardous phenomena world-wide. Successful mitigation of this hazard can be made only with detailed knowledge and database of particular events. Most published works on landslide hazard mapping deal with landslide susceptibility mapping (Dahal et al 2008). Detailed knowledge and databases can be generated only through thorough investigation of the landslide sites or case studies of individual landslide events. These site-specific studies of different landslides are required because of the local geological and geographic heterogeneities found within a small area. This approach to landslide study helps to highlight the types and characteristics of landslides within the study area. Moreover, this approach helps to make decisions on remedial measures for this hazard. Many similar case studies have been carried out (Dutta 1966, Paul 1973, Chatterjee 1975, Basu and Sarkar 1985, Froehlich et al 1991, Bhattacharya 1999, Basu 2000, 2001, De 2002, De et al 2008, Okendro 2006, Anbarasu et al 2010, Ayala et al 2012, Barla et al 2013). The present study is the outcome of a systematic and detailed geophysical investigation to define every detail of the landslide. The geomorphological characteristics have been studied through measurement of micro-slope (facet or smallest unit of the slope), terrain modeling of the scar, determining the total volume of the displaced material and the total area affected by landslides. The seismo-tectonic and geophysical characteristics have been studied through the analysis of earthquake events in this region, geoelectrical resistivity of rocks, lithological and structural characteristics. The rainfall patterns have been considered in order to understand the influence of rainfall on landslide events. Human modifications of the slopes have also been studied and management plans have been proposed to reduce the hazard and associated damage.

\section{Location of the Landslide}

A large landslide has occurred along the slopes of Tertiary Surma deposits at Atharamura Hill in Tripura, India (Figure 1) in 2005. The Surma group of rock is characterized by the presence of thinly bedded repetition of sandstone, siltstone/shale, mudstone and ferruginous sandstone and it consists Bhuban and Bokabil formation (Nandy 1972). This slide is located about $9 \mathrm{~km}$ west from Ambassa, the district headquarters of Dhalai District. Intrinsic geological instability and intense rainfall are the main causes of this landslide. Boarder Road Organization (BRO) has taken some remedial measures to control this landslide, but it reactivates in every rainy season. The landslide scar is surrounded by vegetation and bushes. The whole landslide scar is composed of highly fragile rocks, which allow water to percolate readily and promotes deep weathering of the rocks. Formation of a thick top soil cover of about 1 to $3 \mathrm{~m}$ also helps to percolate rainwater downward. The altitude of the slide varies from $95 \mathrm{~m}-129 \mathrm{~m}$ asl with a convex slope ranging from $15^{0}$ to $75^{0}$. The height of the scar is about 34 $\mathrm{m}$ and dip ranges between $40^{\circ}$ and $45^{\circ}$ in a S-SW direction. Unconsolidated sandy materials with occasional intercalation of moderate to poorly sorted silt or clay layers, continuous seepage through the fractures and cutting of hillslopes for reconstructing and widening of the road (NH-44) have been found responsible for the occurrence of such menace which is further triggered by heavy and concentrated rainfall during monsoon periods. The area receives rainfall mainly from SW monsoon which commences in June and lasts till September. Storms and thunder showers are common during pre monsoon season. Average annual rainfall is very high $(2194 \mathrm{~mm})$ in the study area and $70 \%$ of total annual rainfall occurs during the monsoon season (between June and September). In general, the temperature varies from $20{ }^{\circ} \mathrm{C}$ to $34{ }^{\circ} \mathrm{C}$ for the most part of the year. Maximum and minimum temperature recorded during the year 2010 is $34.1^{\circ} \mathrm{C}$ (April) and $9.2^{\circ} \mathrm{C}$ (January), respectively. 


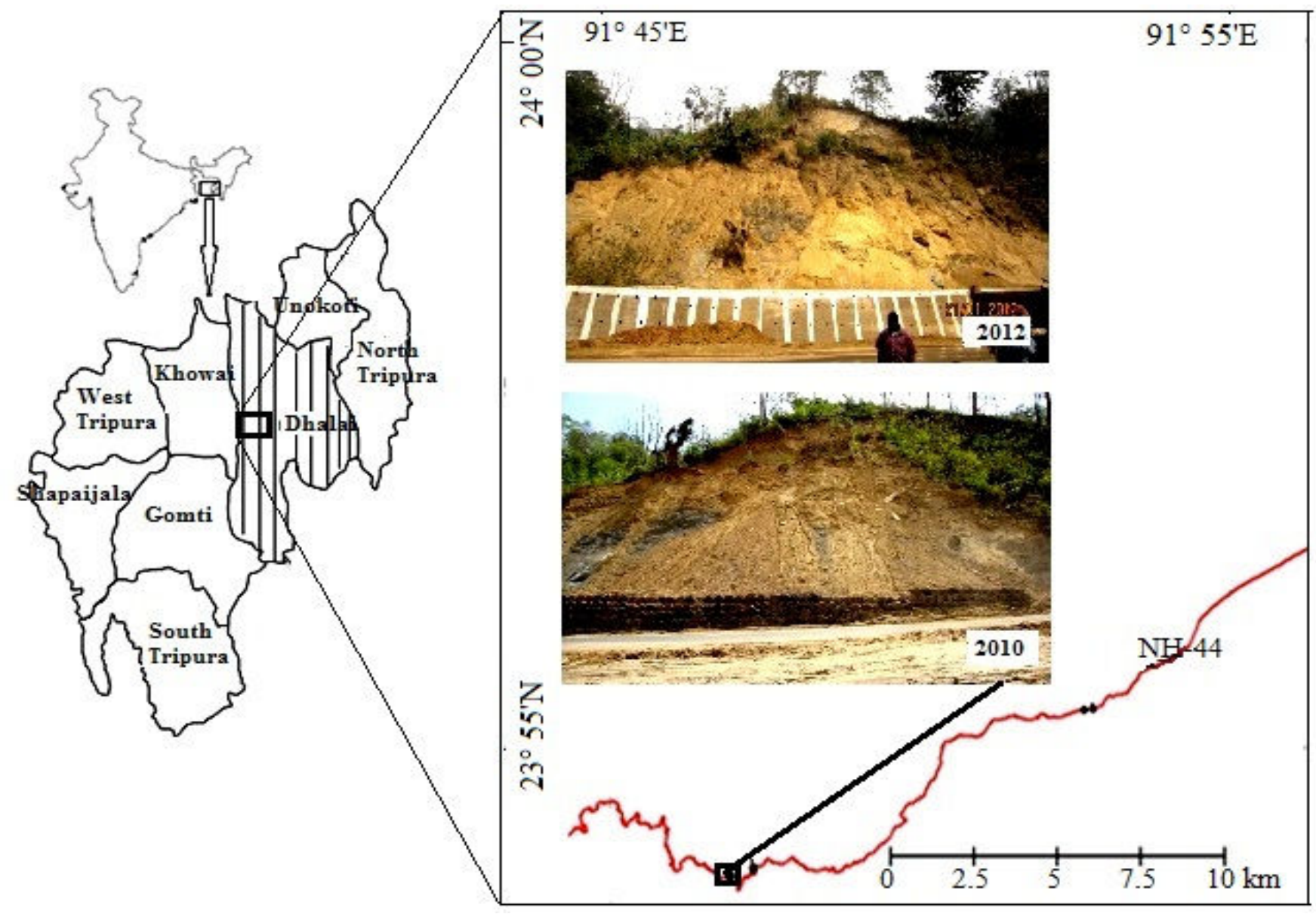

Figure 1. Location map of the Ambassa landslide

\section{Methodology}

The present study has been carried out by using different types of primary, as well as secondary data. The detailed field survey was conducted after a long gap following the landslide event. The field investigation was carried out from 2010 to 2013. During this time period spatio-temporal change of the landslide scar was estimated. Firstly, the location of the landslide scar was marked using GPS. In order to understand the geomorphological characteristics, the whole landslide scar was surveyed by using Total Station. Data of 84 points were recorded from the scar. These data were imported to LISCAD software and contouring at $2 \mathrm{~m}$ interval was carried out. In order to get the terrain condition of the scar, the Digital Terrain Modem (DTM) was prepared from these data sets. For understanding the relationship between geology and the landslide, the geological map of the study area was based on the geological map of the Geological Survey of India (GSI) and Oil and Natural Gas Corporation (ONGC). The lineament map was prepared from IRS P6-LISS III image. The lineaments were extracted by image enhancing method and by using lineament extraction tool in PCI Geometica 10.1 software. The lineament buffer at $50 \mathrm{~m}, 150 \mathrm{~m}$ and $250 \mathrm{~m}$ were delineated and the landslide spot was superimposed. The lithological variation was also analyzed through field surveys. The seismic data of the last 20 years (1982 - 2011) were collected from the published report of disaster management plan, Govt. of Tripura (2011-12). The Geoelectrical resistivity survey has been carried out by using Soil Resistivity Meter (SRM). Geoelectrical mapping was done at two points. The instrumental reading was taken up to $5 \mathrm{~m}$ depth at $1 \mathrm{~m}$ interval. The rainfall characteristics of the study area were analyzed by using the rainfall data of Ambassa rain gauge station. The pre- 
monsoon and monsoon (May - September) rainfall variation of 13 years (2001 - 2013) were studied. In order to understand the landsliderainfall relationship, the daily and cumulative rainfall analysis of the months of May and June, 2010, was also carried out. The management plans were proposed mainly based on field investigation. For recommended slope gradient (vertical distance divided by horizontal distance), a cross section was taken across the middle of the scar and separated into six segments. Slope distance and slope angles were measured at all segments and soil samples were collected and tested in soil testing laboratory. A litho-column along the cross section was also prepared. Based on the slope length, slope angle, soil characteristics and lithological properties, the gradient of the cut slope segments was recommended. For drainage system of the landslide, the present drainage condition was studied and, based on the field survey, a new drainage system was proposed. The existing length of the retaining wall was measured and the horizontal and vertical extension was proposed.

\section{Geophysical and Seismic Characteristics of the Landslide Area}

\subsection{Lithology and structural characteristics}

The rock type in the landslide prone area is part of the Tertiary Bhuban formation (Figure 2A). That formation consists of unconsolidated sandy materials with occasional intercalation of moderate to poorly sorted silt or clay layers. The whole slope is composed of highly weathered and fragile shale and mudstone. They are relatively weak in resistance and favour the development of landslides. In some parts of the slope, coarse grained sand with mud balls (Plate 1A) was also found. The whole landslide scar is mainly composed of huge thickness of laminated siltstone, shale with narrow bands of sandstone; occasionally lenticular structure of medium to coarse sandstone with mudstone (Plate 1B). The present study area is characterized by the presence of large number of strike-slip fault. Most of the fault lines are in SW - NE direction. The altitude of the slide varies from $166 \mathrm{~m}-191$ $\mathrm{m}$ asl with a convex slope ranging from $15^{\circ}$ to $75^{\circ}$. Dip of the rock strata ranges between $40^{\circ}$ to $45^{\circ}$ in SSW direction. The alignment of the bedding indicates two major directions from which deposition started, i.e., northwest to southeast, and north to southeast trends. The present landslide is located within $150 \mathrm{~m}$ buffer zone of fault line (Figure 2B).

\subsection{Seismic events}

North-eastern part of India is one of the six most active tectonic areas in the world and experiences earthquakes frequently. It is placed in zone 5, the highest seismic hazard zone in seismic hazard zonation map of India (Figure 3). It lies at the junction of Himalayan arc to the north and

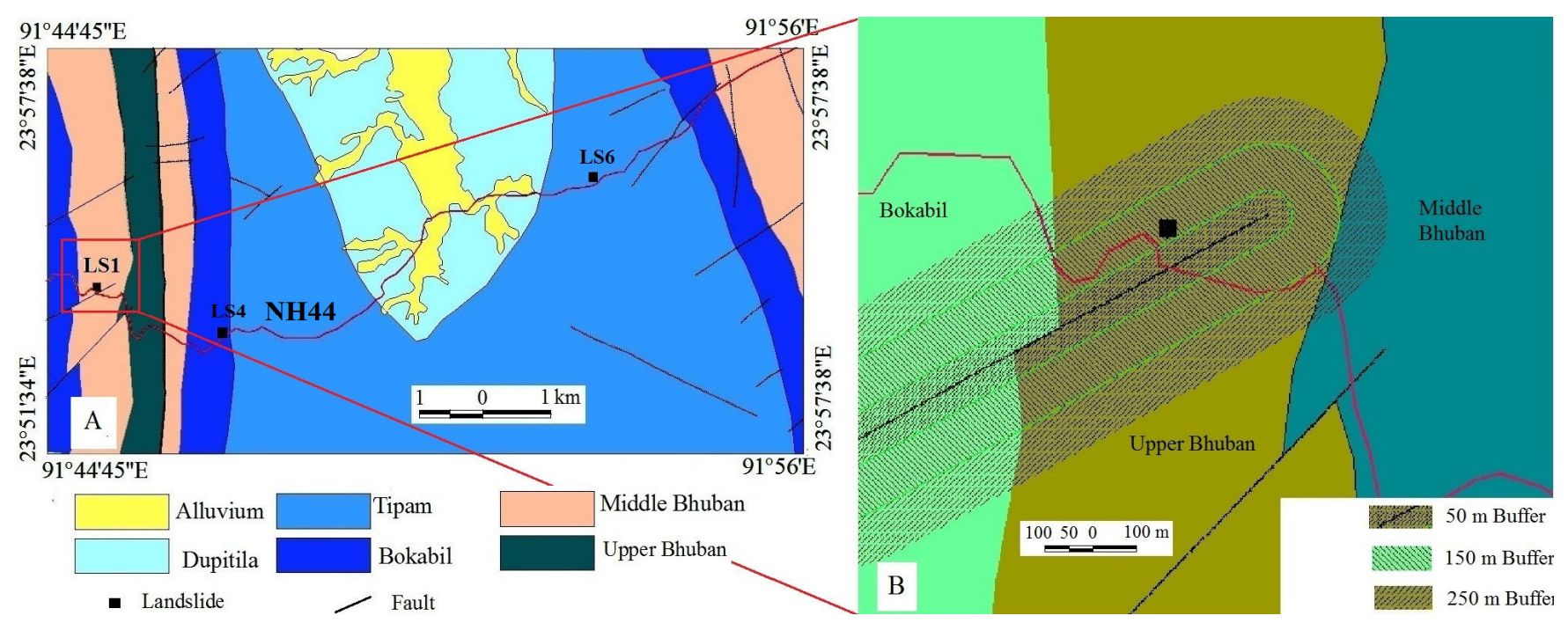

Figure 2. (A) Geology of the area. (B) Fault buffer with the landslide location (Source: Geological map of ONGC and GSI) 

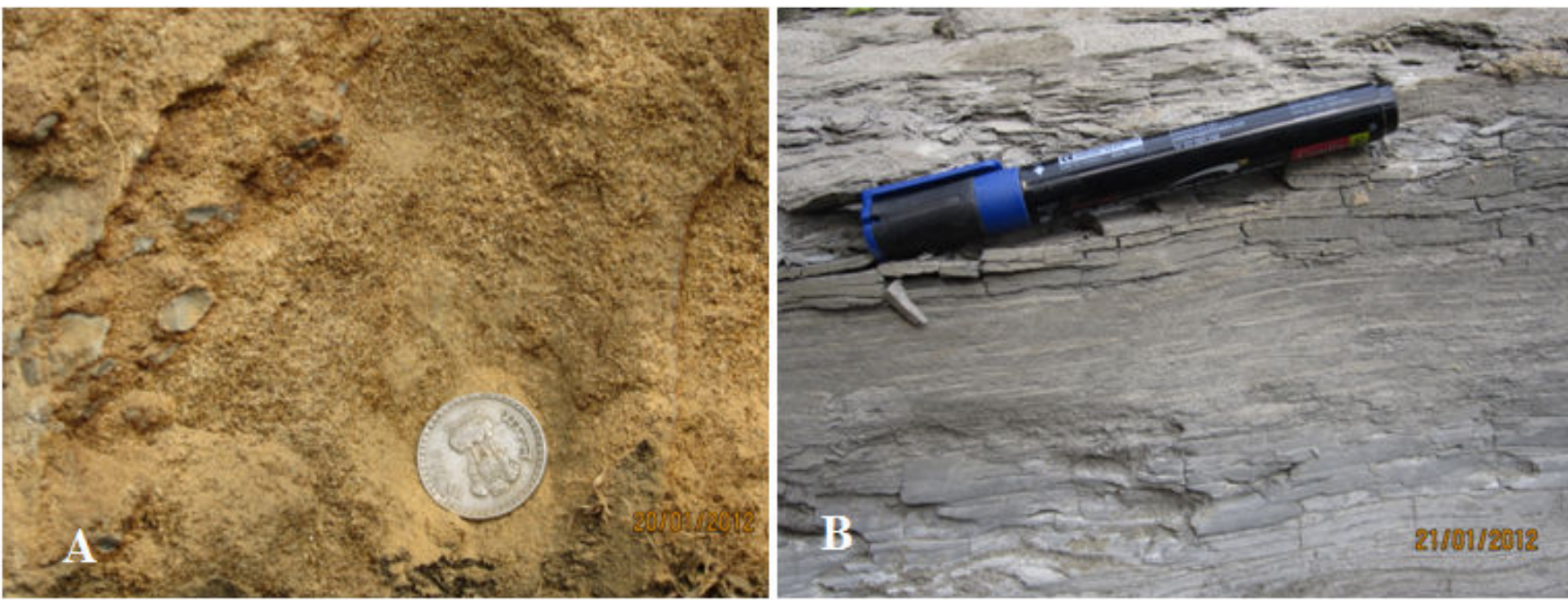

Plate 1. (A) Coarse grained sands with occasional mud balls, (B) Laminated siltstone with occasional very thin laminated sands

Table 1. The recent seismic events in and around Tripura from 1980 to 2011 (with the magnitude and depth ranges)

\begin{tabular}{cccccc}
\hline Sl. No. & Year & Latitude & Longitude & Depth & Magnitude \\
\hline 1. & 1882 & 25.40 & 91.50 & 32.0 & 5.0 \\
\hline 2. & 1984 & 24.20 & 93.50 & 31.0 & 5.7 \\
\hline 3. & 1984 & 25.40 & 91.50 & 34.0 & 5.0 \\
\hline 4. & 1984 & 24.70 & 92.90 & 3.00 & 5.5 \\
\hline 5. & 1986 & 23.90 & 93.00 & 30.0 & 5.2 \\
\hline 6. & 1986 & 25.10 & 91.10 & 17.0 & 5.2 \\
\hline 7. & 1986 & 25.40 & 92.20 & 47.0 & 5.3 \\
\hline 8. & 1988 & 24.70 & 91.60 & 33.0 & 5.8 \\
\hline 9. & 1989 & 24.40 & 92.40 & 10.0 & 5.0 \\
\hline 10. & 1992 & 25.20 & 92.20 & 33.0 & 5.0 \\
\hline 11. & 2011 & & & 88.0 & 6.6 \\
\hline
\end{tabular}

Source: Published report of disaster management plan, Govt. of Tripura (2011-12)

Burmese arc to the east. The region has experienced 11 earthquakes $(\mathrm{M} \geq 5)$ during the last thirty years (Table 1). Besides, several hundred small and micro earthquakes have been recorded in the region. The present study area is tectonically very active and a number of fault lines run through this region.

\subsection{Geo-electrical resistivity}

Geo-electrical mapping is an important tool for geotechnical survey of an area. Geological and structural variation can be understood through electrical resistivity of rocks. In the present study area two points were selected for Vertical Electrical Sounding (VES) survey and data generation. On the basis of the recorded resistivity values, the soil/ rocks of this area have been divided into three electro layers namely top soil (resistivity up to $20 \Omega \mathrm{m}$ ), soft rocks (resistivity below $40 \Omega \mathrm{m}$ ), medium rocks (resistivity below $80 \Omega \mathrm{m}$ ). The first Vertical Electric Sounding (VES) point shows the 
minimum resistivity of $2.2 \Omega \mathrm{m}$ that is recorded at the $5 \mathrm{~m}$ depth (Figure 3A). At $4 \mathrm{~m}$ depth, the resistivity is $31.4 \Omega \mathrm{m}$. At the top (1 $\mathrm{m}$ depth) the resistivity was recorded $11.2 \Omega \mathrm{m}$ and gradual increase has been recorded up to $4 \mathrm{~m}$ depth, but at $5 \mathrm{~m}$ depth sharp decrease is recorded. The maximum resistivity is recorded at $4 \mathrm{~m}$ depth. Thus, within a $1 \mathrm{~m}$ depth $(4-5 \mathrm{~m})$ the maximum variation in resistivity was recorded. This kind of sharp negative change in electrical resistivity proves the existence of water bearing strata or very wet soil in these areas (Mukherjee et al 2011). These variations of the resistivity values at different depth suggest that the area belongs to very high geological complexity.

In the second VES point the top soil has a comparatively lower resistivity than in the first VES point. In this point, the minimum $(8.48 \Omega \mathrm{m})$ resistivity was recorded at the top at $1 \mathrm{~m}$ depth. The resistivity of the rocks gradually increases with the gradual increase of depth. The maximum resistivity (54.8) was recorded at $5 \mathrm{~m}$ depth (Figure 3B). The pseudo profile of VES points 1 and 2 is shown in Figure 4.

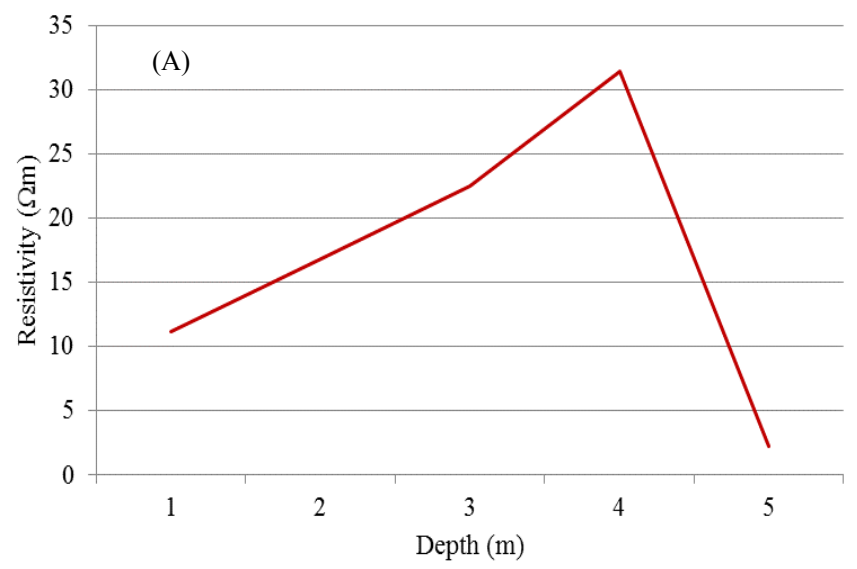

\section{Morphological Characteristics of the Landslide}

The whole landslide failure surface is very complex in nature. Middle portion of the slide experiences translational displacement due to continuous seepage and flow of water and the southern part shows block movement due to presence of fractures. In order to understand the geomorphological characteristics of the slide, contour lines at $2 \mathrm{~m}$ interval (Figure 5). The terrain condition was studied through terrain modeling (Figure 5) of the whole scar, which basically represents $3 \mathrm{D}$ representation of topographic surface. The numbers of facets are more in left side of the scar which represents relatively rough condition of the scar. The slope of the scar varies from $15^{0}$ to $75^{\circ}$. From the Digital Terrain Model it is found that the height of the scar ranges from $95 \mathrm{~m}$ to $129 \mathrm{~m}$ asl. The shape of the whole scar is semi-circular. Field investigations reveal that the landslide covered $1,500.7 \mathrm{~m}^{2}$. Horizontal length of the surveyed scar was $69 \mathrm{~m}$.

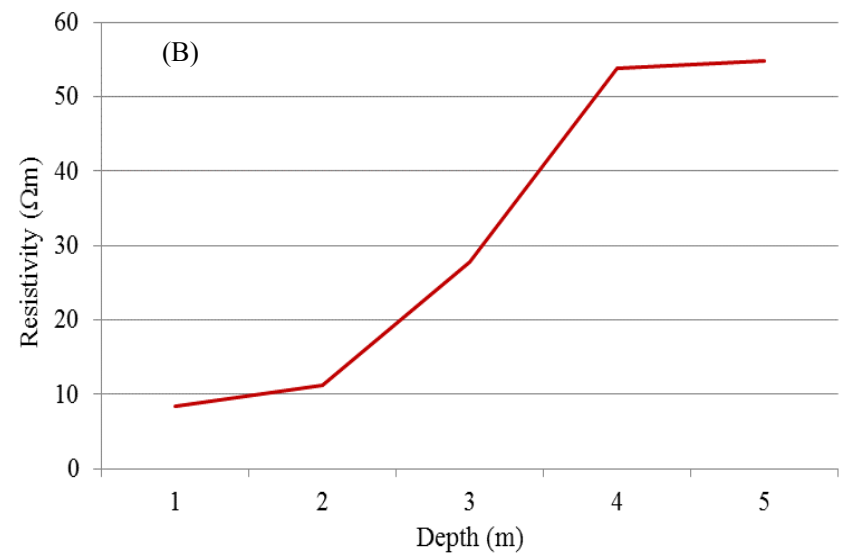

Figure 3. Geo-electrical resistivity of VES point 1 (A) and VES point 2 (B). Source: Field data

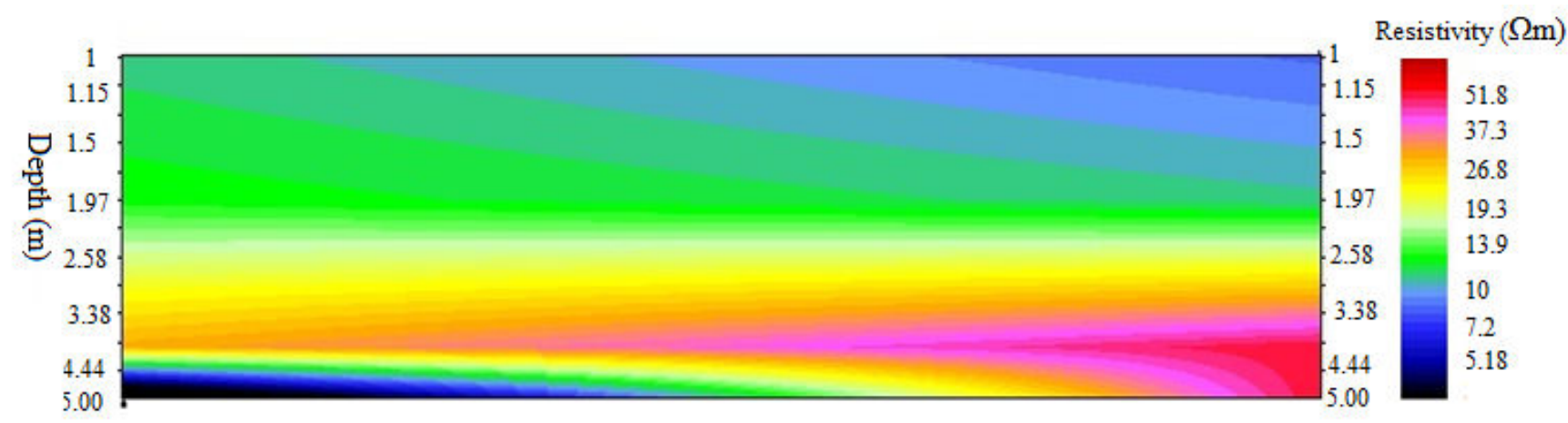

Figure 4. Pseudo profile of geo- electrical resistivity survey of point 1 and 2. Source: Field data 


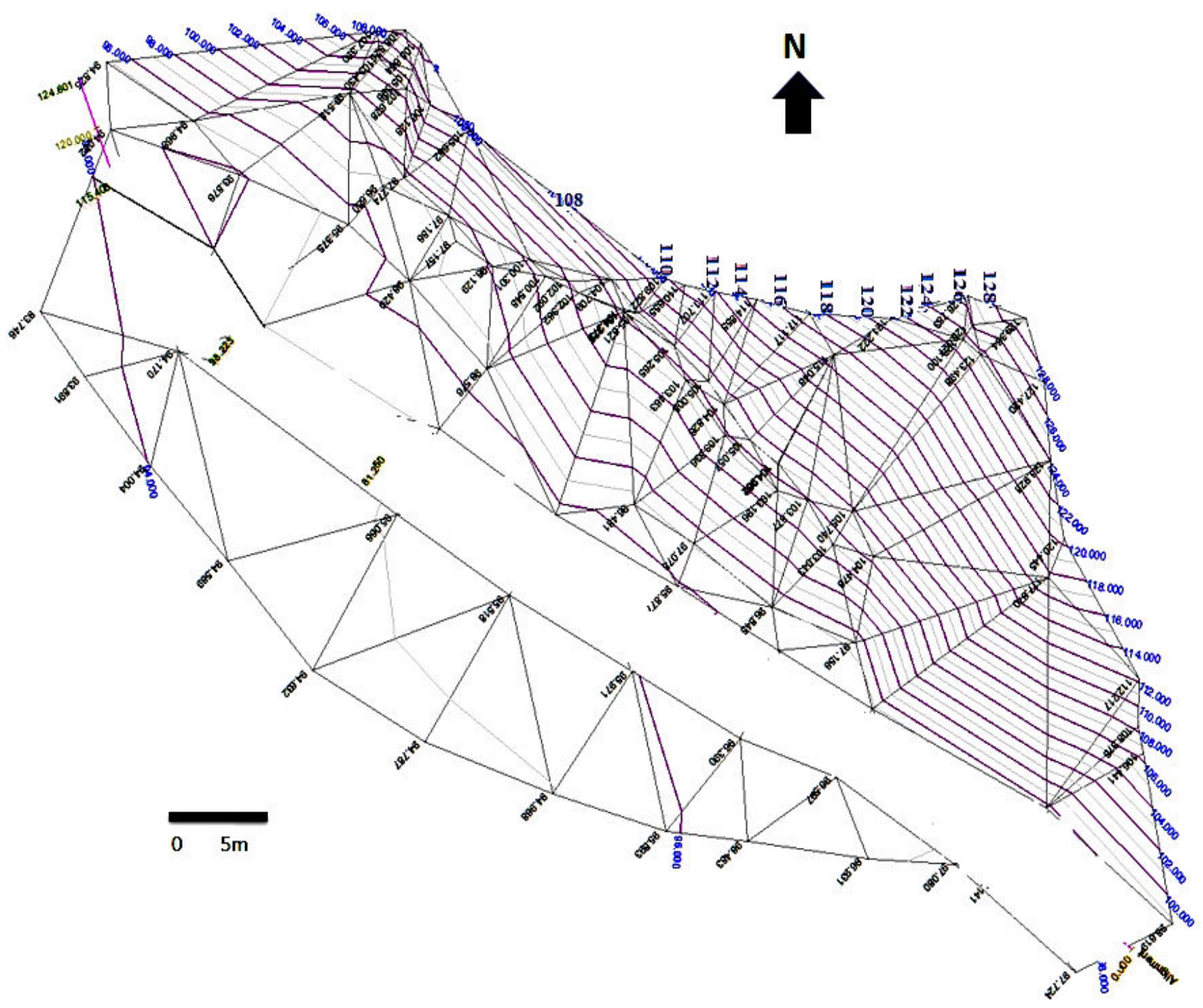

Figure 5. Digital Terrain Model with contour lines of the landslide. Source: Field survey by Total Station

\section{Rainfall Characteristics}

Intense rainfall lasting for a few hours leads to saturation of porous soil and causes a decrease in shear strength of the slope forming materials. In case of the present landslide, the closest rain gauge station (Ambassa) is located about $10 \mathrm{~km}$ east from the landslide location. According to the local respondents, in 2010 this landslide was reactivated after a cumulative rainfall 215.4 of $\mathrm{mm}$ from $1^{\text {st }}-6^{\text {th }}$ June, 2010. This amount of rainfall accounted $46.05 \%$ of the total rainfall of this month. High amount of rainfall is also recorded in the month of May, 2010. It is $525 \mathrm{~mm}$, which is $66 \%$ higher than the annual average rainfall $325 \mathrm{~mm}$ of this month (Figure 6). Before that, from $20^{\text {th }}-31^{\text {st }}$ March, 2010, within ten days,
$445.8 \mathrm{~mm}$ cumulative rainfall has been recorded, which is accounted $84.78 \%$ of the total rainfall of this month. The average annual rainfall is very high in the study area. The area receives rainfall from monsoon. Generally in the month of June, July and August, the amount of average rainfall and number of rainy days are very high. The highest rainfall is recorded as $900.3 \mathrm{~mm}$ in the month of June in the year of 2010. The amount of monthly rainfall varies in great extent. During the years of 2001 - 2013, the average amount of rainfall for the months of May, June, July, August and September were $412.85 \mathrm{~mm}, 555.03 \mathrm{~mm}$, $414.09 \mathrm{~mm}, 399.7 \mathrm{~mm}$ and $27.7 \mathrm{~mm}$, respectively. In the months of May and June 2010, it is observed that 809.1 and $900.3 \mathrm{~mm}$ rainfall exceeded the average rainfall. In the month of 

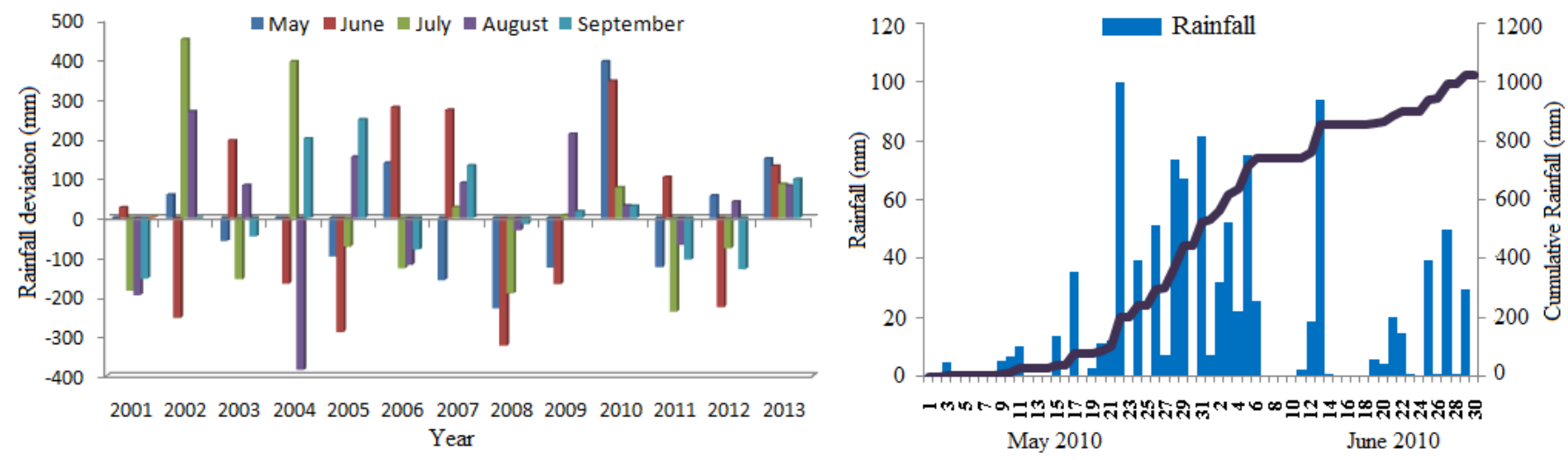

Figure 6. Rainfall variation in the month of May, June, July, August, and September from the year of 2001 to 2013 at Ambassa rain-gauge station

Source: Agricultural Department, Govt. of Tripura

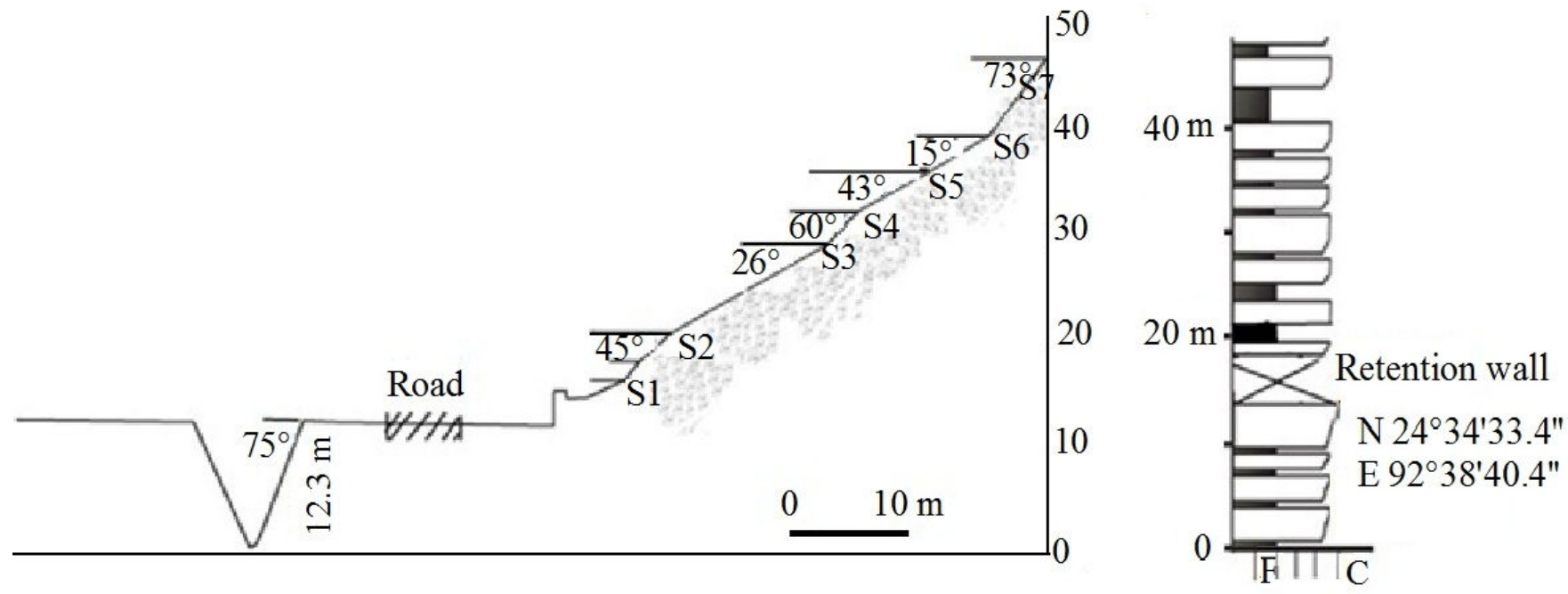

Figure 8. Ground condition of landslide slope. Source: Field data

June, the amount of rainfall was higher than the normal rainfall in the year of 2001, 2003, 2006, 2007, 2010, 2011 and 2013. The maximum deviation of rainfall is observed in July, 2002 and the amount is $429.31 \mathrm{~mm}$ (Figure 7). This excessive rainwater acts as an agent to initiate and accelerate the movement of slope materials. The loose soil allows the rainwater to percolate downward and thereby, subsurface layers get wet and slippery and as a result the slope materials start to move downward. It is observed that the slope is composed of highly fragile rocks and coarse textured soil that allows rain water to percolate downward. This increases the pore water pressure and changes the consistency and shear resistance of the slope material.
Figure 7. Daily and cumulative rainfall distribution in the month of May and June, 2010 
Table 2. Recommended slope gradient for cut slope

\begin{tabular}{|c|c|c|c|c|}
\hline \multirow{2}{*}{$\begin{array}{c}\text { Slope } \\
\text { segment }\end{array}$} & \multicolumn{4}{|c|}{ Ground slope condition } \\
\hline & Lithology & Soil type & $\begin{array}{c}\text { Slope } \\
\text { length }\end{array}$ & $\begin{array}{l}\text { Slope gradient } \\
\text { (V: H) }\end{array}$ \\
\hline S1-S2 & \multirow{4}{*}{$\begin{array}{l}\text { Unconsolidated } \\
\text { Sandstone with } \\
\text { clay alteration }\end{array}$} & Medium sand (Moderately well sorted) & $6 \mathrm{~m}$ & $1: 0.5-1: 1.2$ \\
\hline S2-S3 & & Medium sand (Well sorted) & $15.4 \mathrm{~m}$ & $1.2: 1.5$ \\
\hline S3-S4 & & Fine sand (Poorly sorted) & $8.3 \mathrm{~m}$ & $1: 1.2-1: 1.15$ \\
\hline S4-S5 & & Fine sand (Poorly sorted) & $5 \mathrm{~m}$ & $1: 1.2-1: 1.15$ \\
\hline S5-S6 & \multirow{2}{*}{$\begin{array}{l}\text { (Bhuban } \\
\text { Formation) }\end{array}$} & Medium sand (Moderately well sorted) & $3.2 \mathrm{~m}$ & $1: 0.8-1: 1.0$ \\
\hline S7-S8 & & Medium sand (Moderately sorted) & $8 \mathrm{~m}$ & $1: 1-1: 1.2$ \\
\hline
\end{tabular}

Source: Field data and laboratory testing
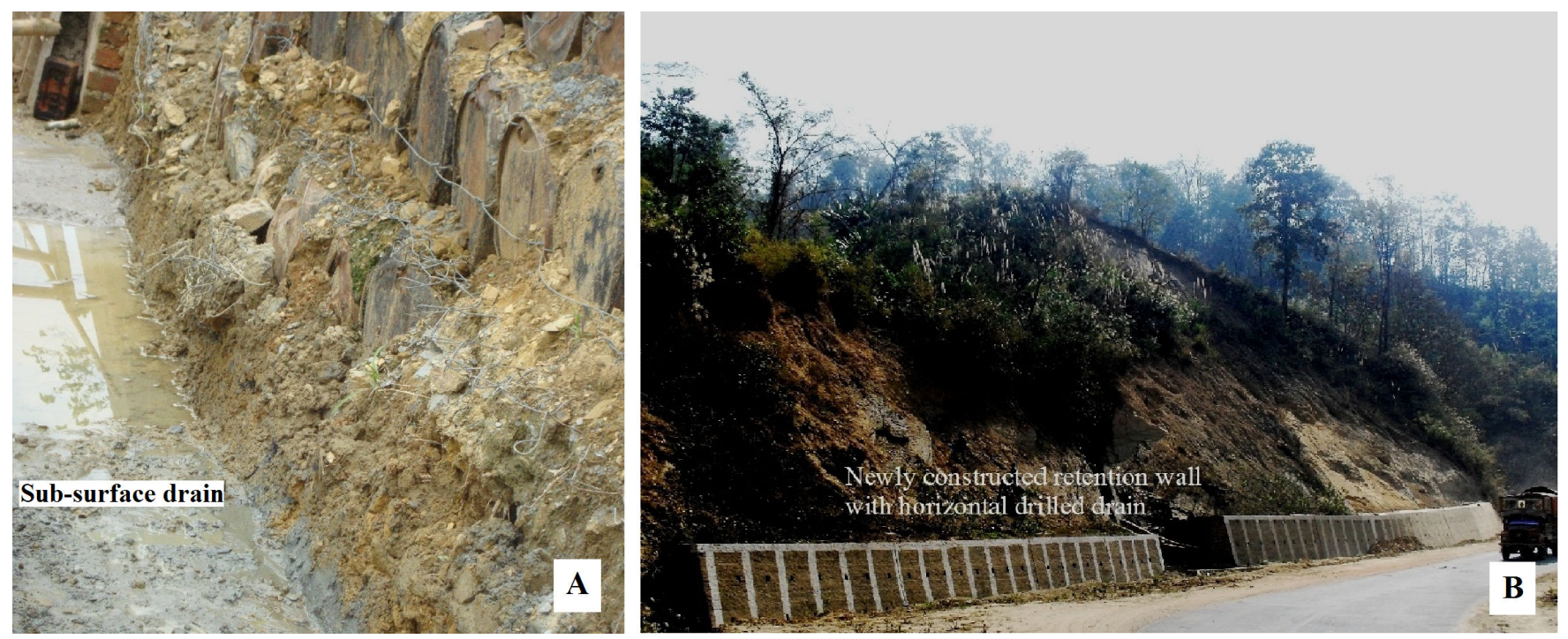

Plate 2 (A). Construction of sub-surface drain (left side); Plate 2 (B). Construction of retention wall with horizontal drilled drains (right side). Source: field survey

characteristics. The recommended cut slope gradient ranges from 1:0.8 to 1:1.2 (V:H, Table 2).

In the present study filling work is not recommended, because the whole slope is made of unconsolidated sandy materials with alternation of thin bedded silt and clay stone. During monsoon season, due to continuous seepage of rainwater, these unconsolidated materials may become heavier and lead to further failure.

\subsection{Subsurface drains and horizontal drilled drain}

The present study area receives high annual rainfall (about $2100 \mathrm{~mm}$ ). Rain water infiltrates into the slope and increases the pore water pressure. Landslides are closely related to shortterm rainfall and surface drainage may be an effective measure. In the present study (Plate 2A and $\mathrm{B}$ ), the whole slope is made up of unconsolidated material, on which surface drains could not be constructed. Thus, instead of only surface drains, subsurface drains and horizontal drilled drains for slope management are also recommended (Figure 9). The subsurface drainage collects the seepage water from surface runoff and reduces the pore water pressure. As the present study area receives high amount of rainfall, it is recommended that the length of the horizontal drilled drain should be equal to the length of the landslide scar. 


\subsection{Retaining wall}

Retaining wall can be constructed to act as an effective barrier to arrest debris or small rock fragments and to prevent displacement at the foot of the landslide. In case of the present landslide, the retaining wall should be extended across the foot of the landslide scar. From the field investigation, it was found that a small section $(21 \mathrm{~m})$ of retaining wall had been constructed. Moreover, both ends of the retaining wall are open. Thus, it is recommended that the retaining wall should be extended across the landslide scar (i.e. as far as both ends of the scar). At right side it should be extended $54 \mathrm{~m}$ more and at middle part by $15 \mathrm{~m}$ and at left side by $12 \mathrm{~m}$. The field survey also revealed that the height $(3 \mathrm{~m})$ of the retaining wall is not adequate to arrest the annual accumulation of debris. Therefore, it is suggested that the height of the retention wall should be extended at least one meter more (Figure 10). The existing retaining wall has been constructed by providing only a single row of horizontal drill drains which may be choked by debris during rainfall. Thus three or four rows of horizontal drill drains are recommended in order to safely drain infiltrated water from the scar.

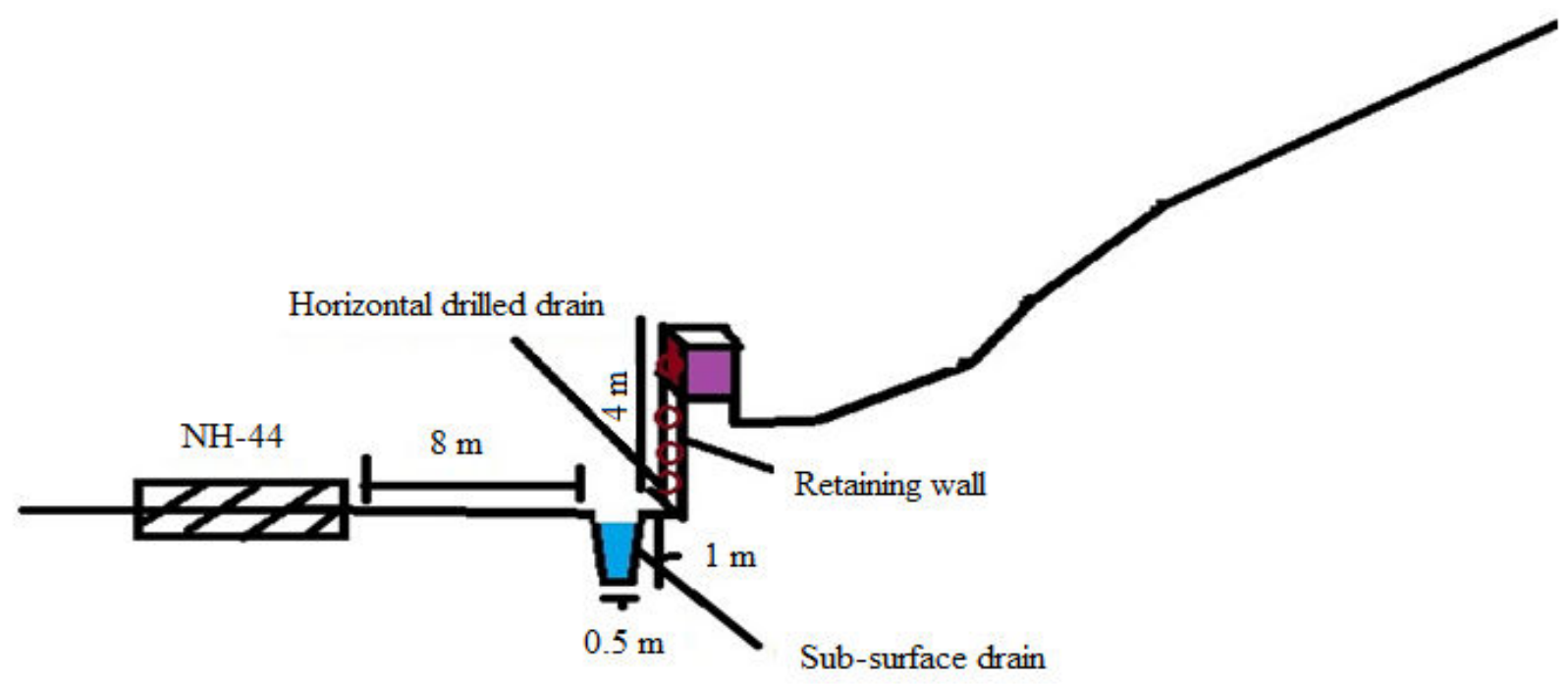

Figure 9. Proposed drains for the landslide

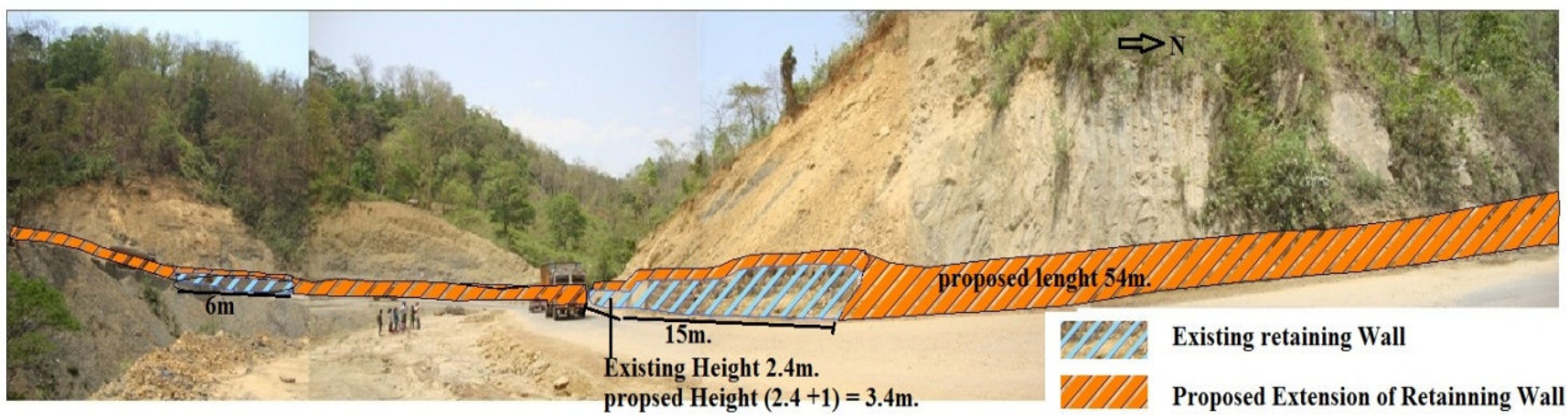

Figure 10. Proposed extension of retaining wall for the landslide

\section{Discussion and Conclusion}

Landslides are most complex phenomena and their successful management depends on in-depth knowledge about the hazard. The landslide events in Atharamura hill, Tripura, have a substantial effect on the operation of road and rail network and frequently cause disruption of transport and communication system. The existing slide poses a threat to the regular road transportation system in 
the hilly area of Tripura. Heavy rainfall during monsoon season acts as the triggering factor for the occurrence of this hazard. The whole landslide scar is mainly composed of huge thickness of laminated siltstone, shale with narrow bands of sandstone; occasionally lenticular bedding structure with medium to coarse grain sandstone with mudstone. The height of the slide varies from $166 \mathrm{~m}$ to $191 \mathrm{~m}$ asl with a convex slope ranging from $15^{\circ}$ to $75^{\circ}$. Dip of the rock strata ranges from $40^{\circ}$ to $45^{\circ}$ in SSW direction. The investigation on the landslide reveals that fragile geological structure and intense rainfall are the main causes of this landslide. In 2010 this landslide was reactivated and $215.4 \mathrm{~mm}$ of cumulative rainfall was recorded from $1^{\text {st }}-6^{\text {th }}$ June, 2010. The landslide is located within $150 \mathrm{~m}$ buffer zone of a fault line which indicates the significant role of neo tectonic activities for the development of landslide events. Moreover, uncontrolled movement of heavily loaded vehicles may play an additional role in creating disturbance along the fault (Sen at al 2015). Variation of geo-electrical resistivity shows the geological complex character of this area. The first Vertical Electric Sounding (VES) point shows that the resistivity ranges from $2.2 \Omega \mathrm{m}$ (5 m depth) to $31.4 \Omega \mathrm{m}(4 \mathrm{~m}$ depth) and at second point it varies from $8.48 \Omega \mathrm{m}$ (1 $\mathrm{m}$ depth) to $4.8 \Omega \mathrm{m}(5 \mathrm{~m}$ depth). Therefore, this research work can be helpful for the effective landslide hazard management. Through intensive investigation some management plans such as construction of sub-surface drainage, construction and extension of retaining wall, cutting/filling of slope on the basis of quantitative assessments are recommended. Although some slope management plans have been suggested to prevent the further occurrences of landslides, cutting of hillside slopes should be stopped. Before the construction of new roads or the widening of the existing roads, local geological conditions such as amount of dip, direction of dip, lithological formation and soil characteristics should be studied properly and engineering techniques should be implemented. The result obtained through the present study can be used as basic data to assist slope management, road construction and land use planning. Collaboration management work on landslide hazard reduction between regions, concerned departments, universities, research centers, nongovernmental organizations and local peoples in landslide-prone areas is required for prevention, mitigation and better management of this hazard.

\section{References}

Anbarasu, K., A. Sengupta, S. Gupta and S.P. Sharma, 2010. Mechanism of activation of the Lanta Khola landslide in Sikkim Himalayas. Landslides, 7: 135 - 147.

Ayala, I.A., J.L. García and R.J. Garnica, 2012. On the landslide event in 2010 in the Monarch Butterfly Biosphere Reserve, Angangueo, Michoacán, Mexico. Landslides, 9: 263 - 273.

Barla, G., F. Antolini and M. Barla, 2013. Slope stabilization in difficult conditions: the case study of a debris slide in NW Italian Alps. Landslides, 10: 343 - 355.

Basu, S.R. and S. Sarkar, 1985. Some considerations on recent landslides at Tindharia and their control. Indian Journal of Power \& River Valley Development, 35(11): $188-194$.

Basu, S.R., 2000. Causes of landslides in the Darjiling town of the Eastern Himalaya. In: Bromhead E.N., N. Dixon and M.L. Ibsen (eds.), Landslides in Research, Theory and Practice. Proceedings of the $8^{\text {th }}$ International Symposium on Landslides. Cardiff, UK, Thomas Telford: 133 - 138.

Basu, S.R., 2001. A systematic study of landslides along the arterial routes to Darjeeling and their control. In: Ho, K.K.S. and K.S. Li (eds.), Geotechnical Engineering Meeting Society's Needs. Proceedings of the $14^{\text {th }}$ Southeast Asian Geotechnical Conference, Hong Kong. AA Balkema Publishers: 691 705.

Bhattacharya, S.K., 1999. A constructive approach to landslides through susceptibility zoning and case study in the Rakti Basin of eastern Himalaya. Transactions, Japanese Geomorphological Union, 20(3): 317 - 333.

Chatterjee, B., 1975. Report on the detailed geotechnical investigation for subsidence affected railway colony and narrow gauge hill section of the North-east Frontier Railway in 
Darjeeling District, West Bengal. An unpublished N.F. Railway Report: 1 - 14.

Dahal, R.K., S. Hasegawa, A. Nonomura, M. Yamanaka, T. Masuda and K. Nishino, 2008. GIS-based weights-of-evidence modeling of rainfall-induced landslides in small catchments for landslide susceptibility mapping. Environ Geol, 54: 311 - 324.

De, S.K., 2002. Landslide in the Balasan Basin and their control. In: Basu, S.R. (ed.), Changing Environmental Scenario of the Indian Subcontinent. ACB publication: 182 194.

De, S.K., M. Jamatia and S. Bandyopadhay, 2008. Geo-technical investigation of Mirik Landslide, Darjiling Himalayas. In: H.S. Sharma and V. S. Kale (eds), Geomorphology in India. Prayag Pustak Bhawan, Allahabad: $207-216$.

Dutta, K.K., 1966. Landslips in Darjeeling and neighboring hill slopes in June, 1950. Bulletin of the Geographical Survey of India, Series B 15(1): 7 - 30 .

EM-DAT, 2009. Emergency Management Disaster Database. www.emdat.be/mapsdisaster-types.

Fookes, P.G. and D.D. Wilson, 1966. The geometry of discontinuities and slope failures in Siwalik Clay. Geotechnique, 16(4): 305 320.

Froehlich, W., L. Starkel and I. Kasza, 1991. Ambootia landslide valley in Darjeeling Himalayas active since 1968. Bulletin of the Polish Academy of Sciences, Earth Sciences, 39(2): 1 - 17.
G.S.I., 2009. Geological Survey of India Report. www.portal.gsi.gov.in.

Ghosh, K., S. Bandyopadhyay and S.K. De, 2012 Landslide susceptibility zonation using weight rating based method in GIS: a case study in Dhalai District, Tripura. Indian Journal of Geomorphology, 17(2): 127 - 145.

Mukherjee, G., C. Debbarma, S. Paul and S. Dey, 2011. Electrical resistivity based shallow crustal deformation analysis in an active seismic zone. Indonesian Journal of Geography, 43(2): 170 - 180.

Nandy, D.R., 1972. Style of folding in the MioPliocene of Tripura-Mizoram area and possible role of basement dislocation fabric. Geol. Surv. India Misc. Pub., p31.

Okendro, M., 2006. Geological and Geomorphological studies along NH-53 from Imphal to Nungba with special emphasis on landslide. Ph.D. Thesis, Manipur University.

Paul, D.K., 1973. Report on geo-technical investigation of hill slope stability and alignment of border road under Project Swastik in Darjeeling District, W.B. and Sikkim. Unpublished Geological Survey of India Report.

Sen, S., S. Mitra, C. Debbarma and S.K. De, 2015. Impact of faults on landslide in the Atharamura Hill (along the NH 44), Tripura. Environ Earth Sci, 73: 5289 - 5298.

Varnes, D.J., 1978. Slope movement, types and processes. In: Schuster, R.L. and R.J. Krizek (eds.), Landslides Analysis and Control. Transportation Research Board, National Academy of Sciences, Washington, D.C., Special Report 176: 11 - 33. 